\title{
Internalisasi Nilai Budaya Toraja Dalam Pengembangan Bahan Ajar Membaca Bahasa Indonesia Di SD Kabupaten Tana Toraja
}

\section{Internalization Of The Value Toraja Cultural In The Development Of Teaching Materials To Read Indonesian In SD Tana Toraja District}

\author{
Susanti1 ${ }^{1}$ A. Hamsiah², Asdar² \\ ${ }^{1}$ Magister Pendidikan Dasar, Program Pascasarjana, Universitas Bosowa \\ 2Program Studi Studi Pendidikan Dasar, Program Pascasarjana, Universitas Bosowa \\ E-mail: susantiranda8gmail.com
}

Diterima: 14 Januari 2021/Disetujui 07 Juni 2021

\begin{abstract}
Abstrak. Penelitian ini bertujuan untuk mengetahui dan menganlisis bentuk bahan ajar, kelayakan bahan ajar, kepraktisan bahan ajar, dan keefektifan bahan ajar dalam pembelajaran bahasa Indonesia berbasis nilai budaya Toraja di SD Kabupaten Tana Toraja untuk mengetahui pengaruh dalam proses pembelajaran. Penelitian ini merupakan penelitian pengembangan bahan ajar dengan model Kemp yang sudah di modifikasi. Penelitian ini dilakukan di SD Kabupaten Tana Toraja. Subjek penelitian ini adalah kelas V SDN 221 Inpres Maliba' dan SDN 297 Inpres Kambuno. Teknik pengumpulan data dalam penelitian ini menggunakan angket, LKS, dan observasi. Peneliti mengolah data secara kualitatif dan kuantitatif. Penelitian ini menghasilkan model produk prototipe bahan ajar membaca bahasa Indonesia berbasis nilai budaya Toraja. Hasil uji coba bahan ajar terbatas maupun uji coba lapangan menunjukkan bahwa bahan ajar ini layak digunakan. Dengan demikian dapat kita simpulkan bahwa bahan ajar membaca bahasa Indonesia berbasis nilai budaya Toraja yang terdiri dari bahan ajar, LKS, beserta pedomannya. Selama digunakan dinyatakan valid, praktis, efektif dan layak digunakan.
\end{abstract}

Kata Kunci: Pengembangan Bahan Ajar, Berbasis Nilai Budaya Toraja

\begin{abstract}
This study aims to determine and analyze the form of teaching materials, the feasibility of teaching materials, the practicality of teaching materials, and the effectiveness of teaching materials in Indonesian language learning based on Toraja cultural values in SD Tana Toraja Regency to determine the effect on the learning process. This study is development research of teaching materials with a modified Kemp model. This research was conducted in SD Tana Toraja Regency. The subjects of this study were students in class V SDN 221 Inpres Maliba' and SDN 297 Inpres Kambuno. Data collection techniques in this study used questionnaires, worksheets, and observation. The data was analysed qualitatively and quantitatively. This study produces a prototype product model for reading teaching materials in Indonesian based on Toraja cultural values. The results of trials of limited teaching materials and field trials show that this teaching material is fea sible to use. Thus, we can conclude that the teaching materials for reading Indonesian are based on Toraja cultural values which consist of teaching materials, worksheets, and their guidelines. As it is used, it is valid, practical, effective and proper for use.
\end{abstract}

Keywords: Development of Teaching Materials, Based on Toraja Cultural Values

\section{Pendahuluan}

Era globalisasi merupakan suatu era yang harus dihadapi oleh setiap bangsa dan negara yang ada di dunia ini, tak terkecuali negara Indonesia. Manusia berlomba-lomba untuk melakukan persaingan mutu dan kualitas di berbagai bidang kehidupan, baik pada bidang ekonomi, sosial, budaya, politik teknologi, dan Pendidikan (Darmawan dkk, 2021). Salah satu upaya yang dapat dilakukan oleh manusia untuk meningkatkan SDM yang berkualitas yaitu pendidikan. Pendidikan merupakan suatu hal penting menjadikan manusia berilmu, bertaqwa serta mampu menghadapi tantangan masa depan. Dengan pendidikan akan melahirkan peserta didik yang cerdas serta mempunyai kompetensi dan skill untuk dikembangkan di tengah-tengah masyarakat. Sistem pendidikan nasional adalah keseluruhan unsur komponen pendidikan yang saling berkaitan secara terpadu untuk mencapai tujuan pendidikan nasional, yang didasarkan pada Pancasila dan UUD 1945 yang bersumber pada nilai-nilai agama, kebudayaan nasional Indonesia dan tanggap terhadap tuntutan perubahan zaman.

Kearifan adalah sebuah kemauan untuk menerima pranata yang ada (Amrih, 2008). Dalam sistem pranata sosial masyarakat Jawa, kearifan sudah berlaku sejak jaman Hindhu. Pendidikan Nasional memiliki tujuan yang sangat mulia terhadap individu sebagai peserta didik yaitu membangun dan membentuk pribadi yang memiliki ilmu pengetahuan, meningkatkan kemampuan keterampilan dan mengembangkan kepribadian yang kokoh agar terbentuk karakter yang kuat, tangguh dan kreatif. Selain itu, pendidikan tidak hanya semata-mata mentransferkan nilai-nilai universal tetapi juga mentransformasikan nilai-nilai partikular atau nilai-nilai khusus, yang hidup dalam suatu masyarakat yang konkret, karena kepribadian seseorang terbentuk oleh nilai-nilai tempat mereka dilahirkan, dibesarkan, dan dididik (Jainuddin dkk, 2020). Latar belakang kebudayaan dan nilai-nilai kemanusiaan yang adadi dalam lingkungan masyarakat, dapat membentuk 
kepribadian manusia karena nilai-nilai kebudayaan dapat menimbulkan terwujudnya nilai-nilai kehidupan keluarga, masyarakat lokal, dan masyrakat luar (Jainuddi \& Silalong, 2020).

Bangsa Indonesia memiliki visi pendidikan nasional, yaitu mengembangkan identitas peserta didik supaya bangga menjadi Bangsa Indonesia, yang penuh percaya diri memasuki kehidupan global sebagai orang Indonesia yang berbudaya (Balalembang, 2007. Adakalanya identitas suatu bangsa atau suku terkoyak, baik secara internal maupun eksternal dinamika kehidupan yang sangat cepat dalam masyarakat menguburkan identitas dan kepribadian serta terjajah oleh bangsa asing yang secara potensial dapat mengoyakkan identitas dan kepribadian sebuah bangsa atau suku. Adakalanya identitas suatu bangsa atau suku terkoyak, baik secara internal maupun eksternal dinamika kehidupan yang sangat cepat dalam masyarakat menguburkan identitas dan kepribadian serta terjajah oleh bangsa asing yang secara potensial dapat mengoyakkan identitas dan kepribadian sebuah bangsa atau suku. Pengenalan nilai-nilai budaya yang menjadi identitas diketahui dan dimaknai secara bersama tidak mungkin seseorang dapat memaknai nilai-nilai kemanusiaan yang abstrak. Nilai-nilai kebudayaan itu merupakan jalinan arti dari hasil peradapan manusia, sehingga kreativitas, inovasi, dan akulturasi dalam transmisi budaya menunjukkan bahwa manusia adalah makhluk yang kreatif dan beradab.

Pentingnya pengenalan nilai-nilai budaya sekarang ini mutlak diperlukan bukan hanya di lembaga pendidikan saja, melainkan juga di rumah dan lingkungan sosial. Saat ini, pendidikan karakter bukan lagi hanya untuk anak usia dini hingga remaja melainkan juga usia dewasa. Hal ini menunjukkan bahwa pendidikan yang dilandasi dengan nilai-nilai luhur diperlukan untuk kelangsungan hidup bangsa atau suku di Indonesia. Pendidikan yang bermuatan pada nilai budaya menjadi salah satu wahana utama untuk mengembangkan karakter yang dapat juga membangkitkan dan menguatkan kesadaran serta keyakinan peserta didik untuk selalu bertindak lebih baik. Pendidikan bermuatan nilai-nilai budaya ini sudah mulai diberikan dari jenjang PAUD sampai perguruan tinggi, yang dipahami sebagai suatu kebenaran bahwa tidak ada manusia yang hidup di masyarakat tidak didasari dengan nilai-nilai budaya yang diakui dalam masyarakt tersebut. Nilai-nilai budaya harus dipahami sebagai sebuah konsep yang perlu ditransformasikan sesuai dengan kondisi masyarakat dewasa ini.

Dalam suatu seminar yang dilaksanakan oleh Sosialisasi Lembaga Adat yang diprakarsai oleh Dinas Kebudayaan dan Pariwisata Provinsi Sulawesi Selatan, Abu Hamid memaparkan (9 November 2014), "Generasi muda sekarang yang telah tumbuh sebagai lost generation", harus menyadari pentingnya pemahaman akan nilai-nilai budayanya yang agung, sebelum nilai-nilai budaya asing menggusurrnya dengan gelombang raksasa kosmopolitanisme yang berakibat pada westernisasi dan modernisasi. Nilai-nilai budaya harus dipahami sebagai sebuah konsep yang perlu ditransformasikan sesuai dengan kondisi masyarakat dewasa ini. Ada kecendrungan, semakin tinggi pendidikan modern yang diterima oleh generasi muda.

Sebagai identitas modern, generasi muda merasa lebih bergengsi dan bangga apabila mereka dapat mengakses atribut modern daripada mengakses identitas lokal tradisional yang dianggapnya sebagai identitas kampungan yang tertinggal oleh zaman, demikian pula dalam hal tata karma baik etika, moral, seni dan estetika serta agama. Harus kita ketahui bahwa pendidikan formal belum sepenuhnya mendukung perkembangan yang menyentuh nilai-nilai budaya lokal tradisional. Dari berbagai peristiwa yang marak terjadi dalam kehidupan sosial menggambarkan bahwa kepribadian atau karakter yang dimiliki oleh sebagian besar masyarakat, baik masyarakat umum, proses pndidikan maupun politik serta penegak hukum telah mengalami degradasi moral. Dalam hal ini, pembenahan yang baik diterapkan adalah pendidikan yang mengacu pada nilai-nilai luhur budaya masyarakat karena kebudayaan tidak lepas dari proses pendidikan.

Salah satu kelemahan juga dalam sistem pendidikan di Indonesia adalah pendidikan yang diterapkan di sekolah termasuk di perguruan tinggi menuntut untuk memaksimalkan komunikasi dan kemampuan proses, sehingga pendidikan yang bermuatan nilai-nilai budaya yang menjadi dasar pembentukan karakter pada peserta didik terabaikan. Dalam kemajuan ilmu pengetahuan dan teknologi sebagai bagian dari pengaruh globalisasi, semakin membuat generasi muda kehilangan semangat untuk mempertahankan budaya lokal yang berisi niali-nilai luhur atau budaya. Berkurangnya semangat ini disebabkan oleh modernisasi budaya yang semakin berkembang yang menawarkan kebebasan dan kemewahan (Fauzi, 2008) dan Gazali (2009). Saat ini pemerintah berupaya untuk menekankan adanya muatan nilai karakter dalam pendidikan untuk semua jenjang agar dapat seimbang. Dengan demikian, pendidikan karakter adalah pendidikan yang menekankan pada pembentukan nilainilai karakter peserta didik.

Dari berbagai peristiwa yang marak terjadi dalam kehidupan sosial menggambarkan bahwa kepribadian atau karakter yang dimiliki oleh sebagian besar masyarakat, baik masyarakat umum, proses pndidikan maupun politik serta penegak hukum telah mengalami degradasi moral. Salah satu kelemahan juga dalam sistem pendidikan di Indonesia adalah pendidikan yang diterapkan di sekolah termasuk di perguruan tinggi menuntut untuk memaksimalkan komunikasi dan kemampuan proses, sehingga pendidikan yang bermuatan nilai-nilai budaya yang menjadi dasar pembentukan karakter pada peserta didik terabaikan. Maka dari itu pemerintah berupaya untuk menekankan adanya muatan nilai karakter dalam pendidikan untuk semua jenjang agar dapat seimbang. Harus kita tahu bahwa pendidikan dan kebudayaan tidak bisa dipisahkan karena saat ini manusia butuh identitas diri sebagai warisan budaya, kearifan lokal budaya Toraja perlu dipelihara dan dilestarikan keberadaannya dalam budaya lokal.

Nilai-nilai budaya Toraja merupaka identitas budaya lokal yang dapat dikaji dan dikembangkan menjadi salah satu materi pembelajaran bahasa di lembaga pendidikan Sulawesi Selatan. Hal ini dilakukan untuk pelestarian budaya lokal yang banyak terdapat nilai-nilai luhur di dalamnya. Nilai-nilai budaya itu dijadikan sebagai dasar dalam pemberian materi atau mengembangkannya dalam proses pembelajaran Bahasa Indonesia untuk mencapai tujuan pendidikan yaitu menciptakan manusia yang cerdas dan berkarakter. Penelitian yang akan dilakukan yaitu dengan mentransformasikan nilai-nilai budaya Toraja menjadi bahan ajar konsep yang mengandung nilai-nilai luhur (Bararuallo, 2010). Dalam hal ini kita tidak bisa lepas dari kurikulum untuk mencapai tujuan pendidikan. Pendidikan yang berbasis pada nilai-nilai budaya dapat berfungsi sebagai pembangun karakter, yang menjadi suatu keharusan dalam pendidikan. Dalam hal ini tidak hanya menjadikan peserta didik 
menjadi cerdas, tetapi juga mempunyai budi pekerti dan sopan santun, sehingga keberadaannya sebagai anggota masyarakat menjadi bermakna baik untuk dirinya maupun orang lain.

Penelitian yang akan dilakukan ini sangat penting sebagai proses pelestarian identitas suku Toraja, dilakukan dengan cara memberikan kebebasan untuk berkembang dan menerapkannnya dalam pengajaran yang berarti memberikan ruang untuk perlindungan dan pemeliharaan tradisi atau nilai-nilai budaya. Selain itu untuk menyikapi kondisi saat ini generasi muda semakin kurang minatnya untuk belajar mengenai tentang nilai-nilai budaya tradisi daerahnya karena, mereka lebih tertarik pada kebiasaan daerah lain dimana mereka menuntut ilmu maka dari itu peneliti melakukan penelitian ini untuk mengenalkan lebih dini kepada anak-anak atau generasi muda untuk tetap mencintai budaya daerahnya (Donzelli, 2003). Meskipun bahan ajar yag dihasilkan nanti tidak digunakan secara umum karena kurikulum 2013 yang sudah permanen dari pemerintah, tetapi bisa menjadi bahan alternatif membaca di sekolah untuk menambah pengetahuan tentang nilai budaya daerah (Depdiknas, 2003). Hal lain yang menjadi alasan dilakukan penelitian ini yaitu budaya Toraja mengandung nilai kebersamaan, nilai kereligiusan, nilai keuletan, nilai kepedulian dan nilai sosial dalam hubungannya dengan sesama makhluk, dan hubungannnya dengan Tuhan..

\section{Metode Penelitian}

Jenis penelitian ini adalah pengembangan bahan ajar dengan model pembelajaran Kemp yang sudah di modifikasi. Banathy dalam Gatot (2008) menyatakan bahwa pengembangan bahan ajar adalah suatu proses yang sistematis dan mengidentifikasi, mengembangkan, serta mengevaluasi isi dan strategi pembelajaran yang diarahkan untuk mencapai tujuan pembelajaran secara lebih efektif dan lebih efisien. Desain penelitian adalah penelitian pengembangan yang berlokasi di Tanah Toraja. Teknik pengumpulan data yaitu: Dokumen berupa naskah nilai budaya Toraja, angket, tes, wawancara dan dokumentasi (Emzir, 2014). Analisis data yang digunakan menggunakan uji t dengan bantuan SPSS.

\section{Hasil dan Pembahasan}

a. $\quad$ Sistematika Pengembangan Bahan Ajar Bahasa Indonesia yang Diinternalisasikan dalam Nilai Budaya Toraja

Data yang disajikan dalam bab ini adalah hasil penelitian yang telah dilaksanakan pada dua sekolah, yaitu SDN 221 Inpres Maliba' dan SDN 297 Inpres Kambuno Kabupaten Tana Toraja. Untuk mengetahui keefektifan bahan ajar membaca Bahasa Indonesia yang diinternalisasikan dalam nilai budaya Toraja pada siswa kelas V sekolah dasar. Deskripsi kegiatan yang dilakukan dalam mendesain bahan ajar Bahasa Indonesia yang diinternalisasikan dengan nilai budaya toraja yaitu, Tahap analisis (analyze), tahap perancangan (design) dan tahap pengembangan (Development).

b. Hasil Uji Bahan Ajar Membaca Bahasa Indonesia yang Diinternalisasikan dengan Nilai Budaya Toraja.

Peneliti memberikan lembar instrumen kepada validator ahli materi dan media yang bernama Dr. Sakaria, M. Pd yang merupakan dosen dari UNM (Universitas Negeri Makassar) untuk validasi bahan ajar Membaca Bahasa Indonesia Berbasis Nilai Budaya Toraja. Peneliti diarahhkan oleh dua pembimbing selama dalam proses pembuatan bahan ajar membaca bahasa Indonesia yang di internalisasikan dengan nilai budaya Toraja untuk sekolah dasar kelas V yaitu Dr. A. Hamsiah, M. Pd dan Dr. Asdar, M. Pd. Setelah mengetahui hasil validasi dari validator untuk semua bentuk kekurangan bahan ajar direvisi kemudian di lakukan uji validasi.

1. Bentuk bahan ajar membaca bahasa Indonesia yang Terinternalisasi Nilai Budaya Toraja

Produk penelitian ini adalah bahan ajar membaca bahasa Indonesia yang diinternalisasikan dengan nilai budaya Toraja yang berbentuk buku. Bahan ajar yang dihasilkan yaitu bahan ajar cetak (printed) dalam bentuk kertas yang dapat berfungsi untuk pembelajaran dan penyampaian informasi. Tata letak dasar memiliki sampul depan, punggung, sampul belakang dan halaman buku. Selain itu bahan ajar ini berbentuk persegi panjang, ukuran sampul yaitu B5 ISO $17,6 \mathrm{~cm}$ X $25 \mathrm{~cm}$ umum \& edukasi. Tinggi buku $17,5 \mathrm{~cm}$, lebar buku $25 \mathrm{~cm}$ dan punggung buku $1 \mathrm{~cm}$ atau menyusaikan ketebalan buku. Ukuran font yang digunakan pada judul buku $15 \mathrm{pt}$ dengan model huruf montserrat extrabold, teks punggung 10pt dengan model huruf montserrat bold, teks penulis 12pt dengan model huruf montserrat semibold dan teks editor 10pt dengan model huruf montserrat semibold. Ukuran font isi bahan ajar 12pt, model huruf times new roman dan spasi $1,5 \mathrm{~cm}$.

2. Kelayakan Bahan Ajar

Dalam menguji kelayakan bahan ajar ada beberapa indikator pernyataan dengan rentang nilai 1 sampai 5.

Tabel 1 Rangkuman Validasi Aspek Isi/Materi Bahan Ajar Ahli Materi

\begin{tabular}{lll}
\hline Aspek & Rerata & Keterangan \\
\hline Kesesuaian materi dengan KI dan KD & 4 & Valid \\
Keakuratan materi & 4,8 & Valid \\
Pendukung materi pembelajaran & 4,8 & Valid \\
Kemuktahiran materi & 5 & Valid \\
\hline Rerata & 4,7 & Valid \\
\hline
\end{tabular}

Sumber: data diolah oleh peneliti (2020)

Keterangan:

1 = sangat kurang $\quad 2$ = kurang baik $3=$ cukup $\quad 4=$ baik $\quad 5=$ sangat baik 
Secara keseluruhan, rerata nilai isi atau materi bahan ajar adalah 4,7 yang artinya bahan ajar valid dari segi isi atau materi telah memenuhi persyaratan untuk diterapkan.

Tabel 2. Rangkuman Validasi Tata Penyajian ModelBahan Ajar Ahli Materi

\begin{tabular}{lll}
\hline Aspek & Rerata & Keterangan \\
\hline Teknik penyajian & 4 & Valid \\
Pendukung penyajian & 4 & Valid \\
Penyajian pembelajaran & 4 & Valid \\
Kelengkapan penyajian & 4,3 & Valid \\
\hline Rerata & 4,1 & Valid \\
\hline
\end{tabular}

Sumber: Data diolah oleh Peneliti (2020)

Secara keseluruhan, rerata dari aspek kelayakan penyajian model bahan ajar yaitu 4,1 dinyatakan valid.

Tabel 3. Rangkuman Validasi Aspek Kelayakan BahasaBahan Ajar Ahli Media

\begin{tabular}{lll}
\hline Aspek & Rerata & Keterangan \\
\hline Lugas & 5 & Valid \\
Komunikatif & 4,5 & Valid \\
Dialogis dan interaktif & 5 & Valid \\
Kesesuaian dengan tingkat perkembangan siswa & 5 & Valid \\
Keruntutan dan keterpaduan alur pikir & 4,5 & Valid \\
Penggunaan istilah, simbol, atau ikon & 4 & Valid \\
\hline Rerata & 4,7 & Valid \\
\hline Sumber: Data diolah oleh Peneliti (2020) & &
\end{tabular}

Sumber: Data diolah oleh Peneliti (2020)

Artinya, jika ditinjau dari segi kelayakan bahasa bahan ajar membaca bahasa Indonesia berbasis nilai budaya Toraja telah memenuhi persyratan untuk digunakan.

Tabel 4. Rangkuman Validasi Aspek Kelayakan Kegrafisan Bahan Ajar Ahli Media

\begin{tabular}{lll}
\hline Aspek & Rerata & Keterangan \\
\hline Ukuran bahan ajar & 4,5 & Valid \\
Desain bahan ajar & 4,7 & Valid \\
Desain isi bahan ajar & 4,9 & Valid \\
\hline Rerata & 4,7 & Valid \\
\hline Sumber: Data diolah oleh Peneliti (2020) & &
\end{tabular}

Tabel di atas menunjukkan rerata total keseluruhan nilai aspek kelayakan kegrafisan yaitu 4,7 yang artinya jika ditinjau dari segi tata grafis, bahan ajar membaca bahasa Indonesia berbasis nilai budaya Toraja telah memenuhi persyratan kelayakan kegrafisan untuk digunakan dalam pembelajaran.

3. Kevalidan Bahan Ajar

Dalam menguji kevalidan bahan ajar ada beberapa indikator pernyataan dengan rentang nilai 1 sampai 5.

Tabel 5. Rangkuman Validasi Aspek Kevalidan Bahan Ajar di Lapanagn

\begin{tabular}{lll}
\hline Aspek & Rerata & Keterangan \\
\hline Penilaian RPP & 4,5 & Valid \\
Penilaian LKS & 4,0 & Valid \\
\hline Rerata & 4,3 & Valid \\
\hline
\end{tabular}

Sumber: Data diolah oleh Peneliti (2020)

Keterangan: 1 = sangat kurang $\quad 2$ = kurang baik 3 = cukup $\quad 4=$ baik $5=$ sangat baik

Jadi rerata aspek kevalidan bahan ajar adalah 4,3 yang artinya sudah memenuhi kriteria dalam penyusunan RPP dan LKS untuk digunakan dalam pembelajaran.

4. Kepraktisan

Hasil uji validasi keparaktisan bahan ajar yang di terapkan dilapangan dalam menguji kepraktisan bahan ajar ada beberapa indikator pernyataan dengan rentang nilai 1 sampai 5.

Tabel 6. Rangkuman Validasi Kepraktisan Bahan Ajar di Lapangan

\begin{tabular}{lll}
\hline Indikator & Rerata & Keterangan \\
\hline Kemudahan dalam menggunakan bahan ajar & 5,0 & Valid \\
Kejelasan bahan ajar & 5,0 & Valid \\
Menarik & 5,0 & Valid \\
\hline Rerata & 5,0 & Valid \\
\hline
\end{tabular}

Sumber: Data diolah oleh Peneliti (2020)

Jadi rerata dari kepraktisan bahan ajar ini valid dengan nilai rata-rata 5,0 yang artinya praktis digunakan dalam pembelajaran. Bahan ajar praktis digunakan karena pada saat mengajar kita hanya menggunakan satu buku yang didalamnya sudah ada KI, KD, indikator, tujuan pembelajaran dan LKS diakhir materi. Senada dengan itu ada juga

5. Keefektifan Bahan Ajar

Dalam menguji keefektifan bahan ajar ada beberapa indikator pernyataan dengan rentang nilai 1 sampai 5 .

Keterangan: 
Tabel 7. Rangkuman Aspek Keefektifan Bahan Ajar di Lapangan

\begin{tabular}{lll}
\hline Indikator & Rerata & Keterangan \\
\hline Siswa dapat menjawab pertanyaan dari setiap materi yang disajikan dalam setiap bab & 5,0 & Valid \\
$\begin{array}{l}\text { Siswa dapat mempraktekkan kegiatan yang ada dalam materi tertentu yang } \\
\text { membutuhkan praktek }\end{array}$ & 5,0 & Valid \\
$\begin{array}{l}\text { Siswa mampu memahami materi yang disajikan dalam setiap bab } \\
\text { Dengan menggunakan buku ini siswa lebih tertarik dalam belajar }\end{array}$ & 5,0 & Valid \\
$\begin{array}{l}\text { Dengan adanya penjelasan dan gambar dalam setiap materi membuat siswa tertarik } \\
\text { untuk membaca buku ini }\end{array}$ & 5,0 & Valid \\
\hline Rerata & 5,0 & Valid \\
\hline
\end{tabular}

Sumber: Data diolah oleh Peneliti (2020)

Keterangan: 1 = sangat kurang $\quad 2$ = kurang baik $3=$ cukup $\quad 4$ = baik $5=$ sangat baik

Secara keseluruhan, rerata nilai keefektifan bahan ajar yaitu 5,0 yang artinya valid untuk digunakan dalam pembelajaran.

c. Hasil Belajar Siswa Terhadap Indikator Keefektifan Bahan Ajar

Tabel 8. Rangkuman Hasil Belajar Siswa

\begin{tabular}{ccc}
\hline Sub BAB & Rerata & Rerata \\
& ( SDN 221 INP. MALIBA') & SDN 297 INP. KAMBUNO \\
\hline BAB I & 84,6 & 78,8 \\
BAB II & 86,25 & 79,63 \\
BAB III & 85,83 & 77,13 \\
BAB IV & 86,66 & 78,6 \\
BAB V & 87,5 & 78,33 \\
BAB VI & 87,08 & 78,6 \\
BAB VII & 86,66 & 79,63 \\
BAB VIII & 84,83 & 78 \\
\hline Rata-Rata & 86,176 & 78,6 \\
\hline
\end{tabular}

Sumber: Data diolah oleh Peneliti (2020)

Tabel 8 di atas dapat dilihat hasil uji coba dari dua sekolah, yaitu SDN 221 INP. Maliba' yang menggunakan bahan ajar membaca bahasa Indonesia berbasis nilai budaya Toraja dengan nilai rata-rata 86,176 sedangkan SDN 297 INP. Kambuno yang menggunakan bahan ajar bahasa Indonesia tema 2 udara bersih bagi kesehatan dengan nilai rata-rata 78,6. Dapat dilihat penggunaan bahan ajar yang berkaitan dengan tempat tinggal siswa sangat berpengaruh dalam proses pembelajaran. Jadi bahan ajar membaca bahasa Indonesia berbasis nilai budaya Toraja yang di terapkan di SDN 221 Inp. Maliba' efektif atau memiliki dampak yang baik dalam proses pembelajaran. Selain itu kita dapat melihat hasil belajar siswa melalui uji-t pada Tabel 9.

Tabel 9. Tabel Analisis Data

\begin{tabular}{ccccc}
\hline Siswa & Nilai SDN 297 INP. Kambuno & Nilai SDN 221 INP. Maliba & Perbedaan & X Jumlah soal \\
\hline N & Y1 & Y2 & D1 & D2 \\
1 & 78 & 83 & 5 & 25 \\
2 & 79 & 85 & 6 & 30 \\
3 & 78 & 88 & 10 & 50 \\
4 & 79 & 89 & 10 & 50 \\
5 & 78 & 88 & 9 & 50 \\
6 & 78 & 87 & 4 & 45 \\
7 & 80 & 84 & 6 & 20 \\
8 & 79 & 85 & 4 & 30 \\
9 & 79 & 83 & 8 & 20 \\
10 & 79 & 87 & 10 & 40 \\
11 & 78 & 88 & 9 & 50 \\
12 & 80 & 89 & 91 & 45 \\
\hline Jumlah & 945 & 1036 & & 455 \\
\hline Y & 78,75 & 86,33 & &
\end{tabular}

Sumber: Data diolah oleh Peneliti (2020)

$$
\begin{aligned}
& \left.\mathrm{S}^{2} \mathrm{D}=\left(\sum \mathrm{D} 2-\left(\sum \mathrm{D}\right)^{2}\right) / \mathrm{n}\right) /(\mathrm{n}-1)=\left(\sum 455-(91)^{2} / 12\right) /(12-1) \\
& =(455-690,083) / 11 \\
& =392,2651 \\
& \mathrm{~S}=\sqrt{ } \mathrm{S}^{2} \mathrm{D} / \mathrm{n}=\sqrt{392,2651 / 12=19,8057 / 12} \\
& =1,65047 \\
& \text { T hit }=\left(\mathrm{y}^{1}-\mathrm{y}^{2}\right) / \mathrm{S}=(78,75-86,33) / 1,65047 \\
& =-7,58 / 1,65047 \\
& =-4,592631 \\
& \mathrm{~T} \text { tabel }=\mathrm{t} \mathrm{a} / 2(\mathrm{df})=\mathrm{t} 0,05 / 2(\mathrm{n}-1) \\
& =\mathrm{t} 0,025(12-1) \\
& =\mathrm{t} 0,025(11)=2,201
\end{aligned}
$$


Setelah itu, kita lihat nilai t tabel, sebagai nilai pembanding. Cara melihatnya yaitu kita lihat kolom a =0,025 pada tabel berasal dari a 0,05 yang dibagi 2. Nilai 11 adalah nilai df yaitu n-1 dimana n menandakan jumlah siswa yaitu 12 orang untuk memperoleh nilai t tabel $=2,201$. Nilai t tabel dapat dilihat pada lampiran halaman 90 .

Dalam menentukan pengambilan kesimpulan ada dua hal yang harus di perhatikan yaitu terima H0 jika $\mathrm{t}$ hitung $<\mathrm{t}$ tabel, sebaliknya tolak H0 jika nilai $\mathrm{t}$ hitung > t tabel. Terima H1 jika t hitung $>\mathrm{t}$ tabel begitupun sebaliknya. Karena nilai $\mathrm{t}$ hitung 4,593 ( tanda minus diabaikan) dan nilai t tabel = 2,201, maka kita tolak H0 dan kita terima H1. Dengan demikian y1 $\neq$ y2 yaitu nilai SDN 297 INP. Kambuno dengan rata-rata 78,75 tidak sama dengan nilai SDN 221 INP. Maliba' rata-rata 86,33. Kita dapat menyimpulkan bahwa bahan ajar membaca bahasa Indonesia berbasis nilai budaya Toraja efektif digunakan untuk meningkatkan pemahaman siswa terhadap materi ajar yang diberikan.

Berdasarkan hasil analisis data sebelumnya, di ketahui bahwa bahan ajar membaca bahasa Indonesia berbasis nilai budaya Toraja ini sangat bermanfaat dalam pembelajaran bahasa Indonesia. Sehubungan dengan penelitian pengembangan ini telah diadakan pengembangan bahan ajar yang mencakup lima komponen yaitu (1) bahan ajar, (2) panduan bahan ajar, (3) lembar kerja siswa, (4) panduan penggunaan lembar kerja siswa, dan (5) panduan penilaian lembar kerja siswa. Dalam proses pengembangan bahan ajar membaca bahasa Indonesia berbasis nilai budaya Toraja, melalui beberapa perubahan berdasarkan masukan dari validator dan pembimbing. Perubahan yang signifikan dapat dilihat pada sampul buku yang dua kali revisi untuk mendapatkan sampul yang relevan dengan isi buku. Untuk lebih jelas dapat kita lihat pada Gambar 1.

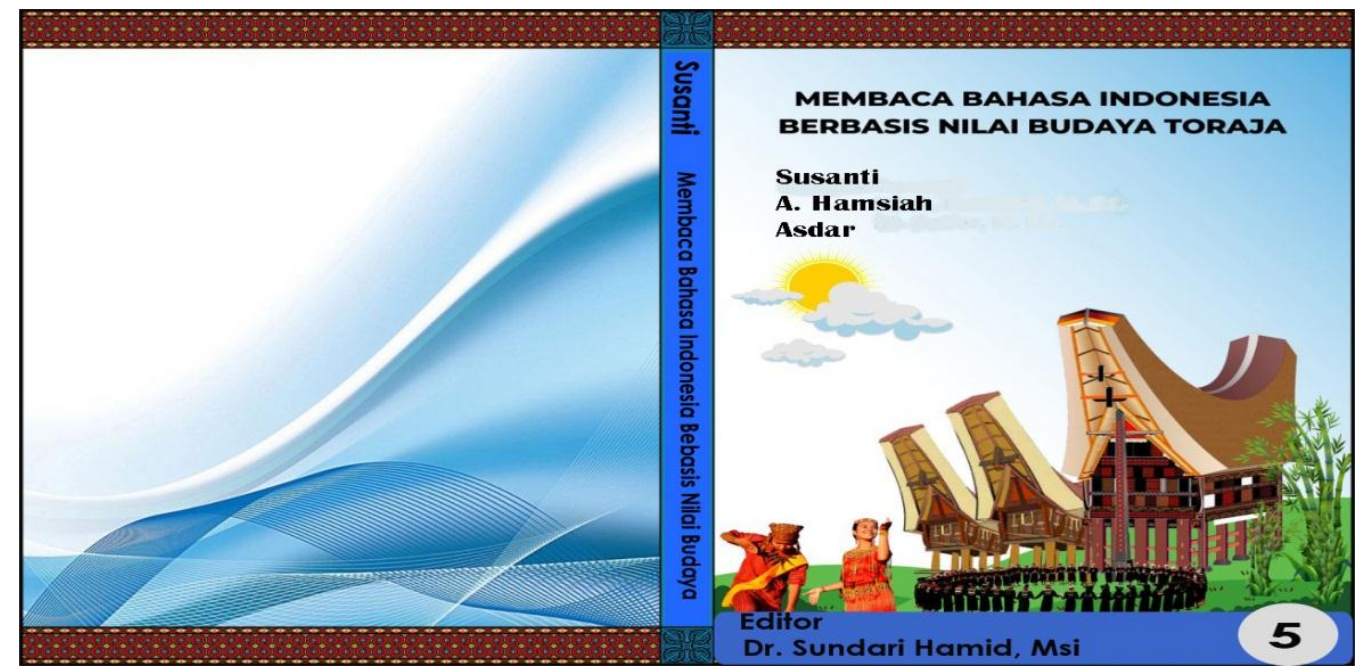

Gambar. 1. Desain Sampul Yang Direvisi

Desain yang kedua yang mengalami perubahan signifikan yaitu materi dalam setiap bab yang awalnya langsung tujuan pembelajaran mengalami perubahan yaitu penambahan KI, KD, Indikator, tujuan pembelajaran untuk memudahkan pengguna buku. Untuk lebih jelas dapat dilihat pada gambar berikut ini.

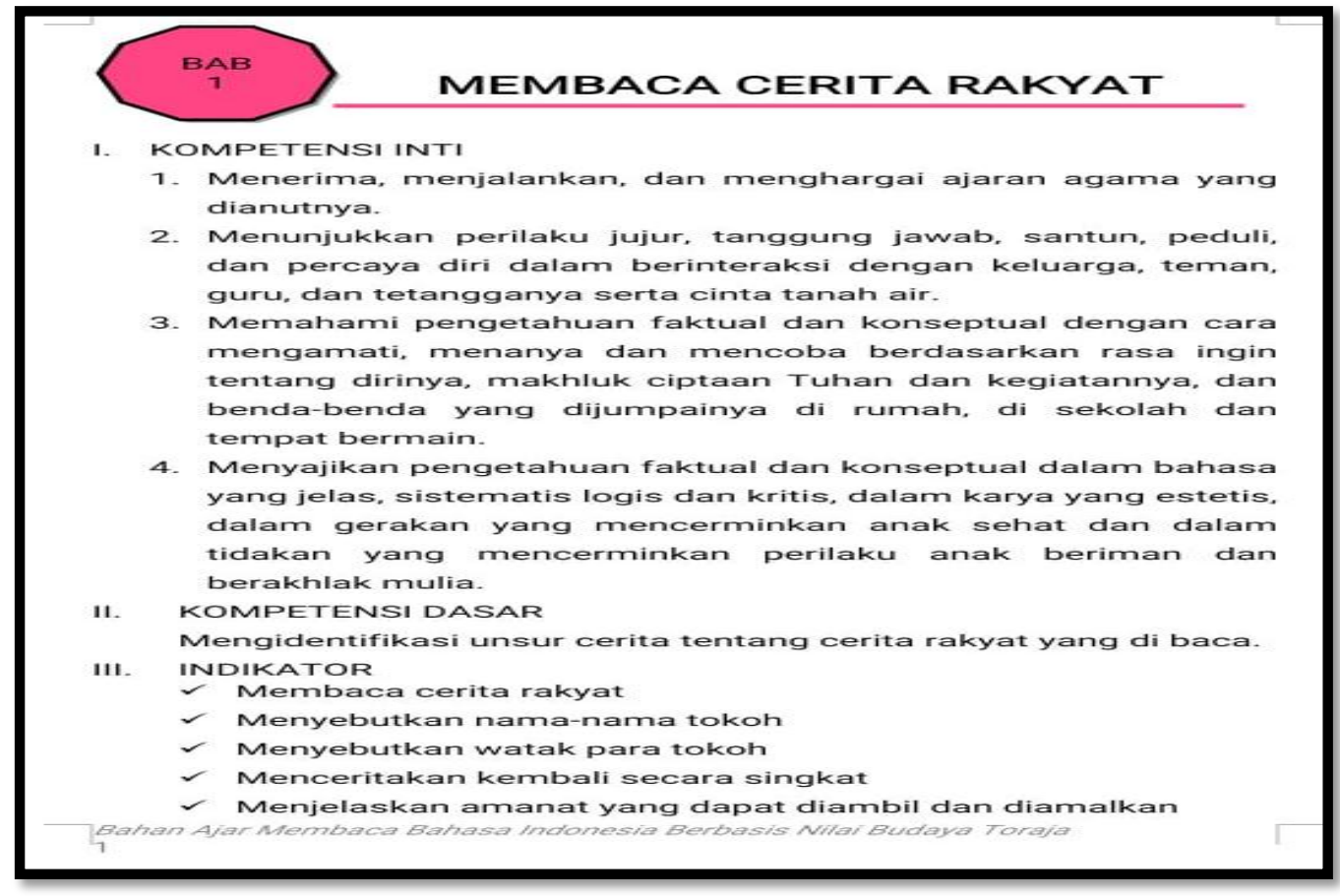

Gambar. 2. Judul Yang Sudah Direvisi

Dalam proses pembelajaran materi yang diberikan berkaitan dengan keadaan siswa atau tempat tinggal siswa, namun tetap mengikuti standar kompetensi dan kompetensi dasar yang ingin dicapai. Siswa lebih aktif dalam mengikuti 
pembelajaran yang di kaitkan dengan tempat tinggal siswa dalam bahan ajar membaca bahasa Indonesia berbasis nilai budaya Toraja. Bahan ajar yang digunakan dalam pembelajaran ini lebih banyak mengarah pada kegiatan membaca. Meskipun banyak membaca siswa tidak bosan karena teks yang di sajikan dalam setiap bab berkaitan dengan tempat tinggal dan kegiatan yang sering diikuti oleh siswa. Materi yang disajikan dalam setiap bab sudah sesuai dengan kebutuhan waktu belajar di sekolah dasar, yaitu 2 X 35 menit (minimal 70 menit). Dalam memberikan materi ini tidak butuh waktu banyak dan tidak sulit karena siswa lebih muda memahami materi sehingga waktunya cukup untuk mencapai tujuan pembelajaran yang akan dicapai.

\section{Kesimpulan dan Saran}

Hasil penelitian dapat disimpulkan bahwa bahan ajar membaca bahasa Indonesia berbasis nilai budaya Toraja yang dilaksanakan di dua sekolah dengan hasil yang efektif. Setelah melalui berbagai prosedur dalam penelitian pengembangan ini yang berorientasi pada penelitian yang menghasilkan produk berupa bahan ajar yang terdiri dari buku bahan ajar membaca bahasa Indonesia berbasis nilai budaya Toraja, petunjuk penggunaan buku, dan lembar kerja siswa (LKS) beserta panduan penggunaannya. Bagi guru, dapat menjadi acuan dalam menyusun bahan ajar kelas V di SD Kabupaten Tana Toraja. Bagi siswa, dengan adanya bahan ajar membaca bahasa Indonesia berbasis nilai budaya Toraja meningkatkan minat baca siswa untuk tetap mencintai budaya daerahnya. Dan bagi peneliti, hasil penelitian ini dapat menjadi acuan bagi peneliti selanjutnya untuk meneliti pengembangan bahan ajar yang berbasis nilai budaya.

\section{Daftar Pustaka}

Arikunto, Suharsimi., dkk. (2008). Penelitian Tindakan Kelas. Jakarta: Bumi Aksara.

Muhsetyo, Gatot. 2008. Pembelajaran Matematika SD. Jakarta: Universitas Terbuka

Jainuddin, J., Silalong, E. S., \& Syamsuddin, A. (2020). Eksplorasi Etnomatematika pada Ukiran Toraja. Delta-Pi: Jurnal Matematika dan Pendidikan Matematika, 9(2).

Jainuddin, J., \& Sirajuddin, S. (2020). Pengaruh Minat dan Kedisiplinan Siswa dengan Gaya Kognitif Field Indefendent terhadap Hasil Belajar Matematika Siswa SMK Farmasi Yamasi Makassar. Delta-Pi: Jurnal Matematika dan Pendidikan Matematika, 9(2).

Darmawan, F. A., \& Jainuddin, J. (2021). Augmented Reality-based Mathematics Worksheet for Online Learning During Covid-19 Pandemic. Indonesian Journal of Educational Studies, 23(2), 81-90.

Balalembang, L. (2007). Ada' Toraya. Tana Toraja: Sulo.

Bararuallo, F. (2010). Kebudayaan Toraja. Yogyakarta: Pohon Cahaya.

Depdiknas. (2003). Undang-Undang No. 20 Tahun 2003, tentang Sistem Pendidikan Nasional. Jakarta: Depdiknas.

Donzelli, A. (2003). Diversity in Unity: Multiple Strategies of a Unifying Rhetoric, the case of Resemanticisation of Toraja Rituals: From Wasteful Pagan Feasts into Modern Auctions. Jurnal Anropologi Indonesia, 72, September-Desember, $38-57$.

Emzir. (2014). Metodoogi Penelitian Pendidikan Kuantitatif dan Kualitatif. Jakarta: Raja Grafindo Persada.

Fauzi, F. (2008). Peran Pendidikan dalam Transformasi Nilai Budaya Lokal di Era Millenial. Insania: Jurnal Pemikiran Alternatif Kependidikan, 23(1), 51-65.

Gazali. (2009). Nyanyian Rakyat Kaili: Struktur, Fungsi dan Nilai (jurnal).

Hamsiah, A., M. M. dan A. (n.d.). Pengembangan Bahan Ajar Berbasis Nilai Budaya Sebagai Strategi Pelestarian Budaya. Ecosystem, 19 (1), 10-18. 2019.

Sugiyono. (2011). Metode Penelitian Kuantitatif Kualitatif dan R\&D. Bandung: Alfabeta. 